\title{
ASTA BUMI DALAM PERSPEKTIF SEJARAH (STUDI KASUS KOTA DI KECAMATAN CAKRANEGARA KOTA MATARAM PROVINSI NUSA TENGGARA BARAT)
}

\author{
Rosada, Muhammad Hario Satria Hariski \\ ${ }^{1,2}$ Dosen Program Studi Pendidikan Sejarah, Universitas Muhammadiyah Mataram \\ Email : ros_ada84@yahoo.co.id
}

\begin{abstract}
ABSTRAK
Republik Indonesia adalah Negara yang terletak di Asia Tengggara yang dilintasi garis khatulistiwa dan berada di antara benua Asia dan Australia serta antara Samudra Pasifik dan Samudra Hindia.Indonesia adalah Negara kepulauan terbesar di dunia yang terdiri dari 13.466 pulau. Tata kota merupakan suatu karya, cipta dan rasa yang direncanakan dengan berbagai konsep oleh manusia seperti latar belakang, visi, misi, serta motivasi dalam merancang suatu kota. Dalam penelitian ini, peneliti akan meneliti berbagai hal tentang 1) Bagaimana ciri khas Asta Bumi yang berada di Kecamatan Cakranegara. 2) Bagaimana pandangan masyarakat Hindu di Kecamatan Cakranegara mengenai Asta Bumi. 3) Bagaimana pandangan akademisi dan pandangan pemerintahan kota Mataram mengenai Asta Bumi di Kecamatan Cakranegara. Dalam penelitian tentang Asta Bumi dalam Persepektif Sejarah (Studi Kasus Tata Kota Kecamatan Cakranegara Kota Mataram Provinsi NTB peneliti menggunakan metode penelitian historis dengan pendekatan kualitatif.
\end{abstract}

Kata Kunci: Asta Bumi, Persepektif Sejarah

\section{PENDAHULUAN}

Tata kota merupakan suatu karya, cipta dan rasa yang direncanakan dengan berbagai konsep oleh manusia seperti latar belakang, visi, misi, serta motivasi dalam merancang suatu kota. Perancangan tata kota harus memenuhi beberapa aspek seperti aspek budaya dan lingkungan (Budiharjo, 2009:138) dimana dari segi ini kota harus memerhatikan budaya yang sudah ada (budaya lokal) di wilayah tersebut sehingga daerah tersebut memiliki ciri khas yang membedakannya dengan kota lainnya, serta daerah tersebut melestarikan warisan nenek moyang mereka. Kemudian lingkungan, dari segi ini tata kota harus menyeimbangkan daerah terbuka serta perumahan sehingga menyeimbangkan kekerabatan serta solidaritas yang tinggi secara alami dengan alam.

Penataan yang mencakup ekonomi merupakan langkah untuk mensejahterakan rakyat. Seperti penataan pasar agar lebih kondusif dan tertata (Nugroho, dkk:2008). Kemudian yang tidak kalah penting perencanaan kota harus dilandaskan UUD 1945 yang menggariskan tujuan negara untuk mewujudkan kesejahteraan umum, mencerdaskan kehidupan bangsa, melindungi segenap bangsa dan tumpah darah Indonesia, serta ikut melaksanakan ketertiban dunia berdasarkan kemerdekaan, perdamaian abadi, dan keadilan sosial. Tujuan pembagunan tersebut akan terwujud bila masalah pembangunan-kesenjangan, penggangguran, kemiskinan dapat diatasi.

Mataram adalah kota dari provinsi NTB yang mencanangkan perbaikan dan membangun pembangunan yang berkelanjutan untuk membantu kegiatan mempromosikan NTB sebagai daerah parawisata. Berbicara tentang Cakranegara, berarti membahas tentang tata kota tradisional dimana sejak jaman Kerajaan Karangasem Lombok mulai terdapat asimilasi antara budaya Bali Hindu dan Sasak. Tata kota ini disebut Asta Bumi. Asta Bumi ini merupakan ilmu tata ruang tradisional Bali yang dilakukan secara turuntemurun.

Asta Bumi ini berawal dari etnis Bali pernah menduduki kawasan Lombok baik oleh Kerajaan Gelgel Bali serta Kerajaan Karang Asem Bali.Hal ini bermula pada abad ke 16 di Bali muncul kekuasaan yang besar dari Kerajaan Gelgel.Kerajaan ini 
mencapai puncak kejayaan pada masa pemerintahan Raja Batu Renggong sekitar tahun 1550.Di sebutkan bahwa pada masa Raja Batu Renggong meluaskan pengaruhnya dari Blambangan, Lombok, serta Sumbawa. Hal ini di buktikan ketika Blambangan mendapat serangan dari Pasuruan, Kerajaan Gelgel mendatangkan pasukan bala bantuan dari Bali, Lombok dan Sumbawa (Parimartha,2014: 21).

Hubungan Bali-Lombok juga bisa dilihat dari dua sumber lokal (Lombok yang keduanya menyebut nama tokoh Pangeran Sangupati (Parimartha, 2014). Pertama di lihat dari manuskrip Pangeran Sangupati, menggunakan bahasa Jawa Kuna bercampur bahasa Bali-Sasak.Ke dua, manuskrip PustakaJatiswara dimana di manuskrip itu Pangeran Sangupati digambarkan sebagai ulama yang mengajarkan agama suci (Islam). Ketika berbicara tentang masyarakat Bali yang menganut agama Hindu dan dianggap kafir, beliau menjelaskan bahwa masyarakat (lokal Lombok) tidak perlu khawatir karena masyarakat Bali merupakan penganut agama "Majapahit". Sehingga masyarakat merasa dekat secara fsikologis karena dulunya Lombok pernah dibawah kekuasaan Majapahit.

Kemudian Kerajaan terakhir yang menanam pengaruh di Lombok yang berasal dari Bali yaitu Karangasem Bali. Hal ini berawal pada tahun 1692 Raden dari Praya Arya Banjar Getas meminta bantuan kepada Gelgel di bawah kepemimpinan Gusti Asem untuk memerangi lawannya yaitu Datu Pejanggik. Kemudian setelah Pejanggik dapat ditaklukkan, kedatuan yang di taklukkan selanjutnya Parwa dan Selaparang. Sehingga pada tahun 1740 Lombok telah di taklukan oleh pasukan gabungan dari Pangeran Arya Banjar Getas dengan Pasukan Gelgel Bali. Kemudian terjadi pembagian kekuasaan dimana bagian barat dimiliki oleh Karangasem dan bagian timur Banjar Getas. Batas antara kedua bagian itu adalah Sweta-Penentang ai', Pelambik, Ranggagata, dan Blonggas.

Pada tahun 1723 ketika Singasari dan mendapat serangan dari Sumbawa dibawah kepemimpinan Amasa Samawa, orang-orang Bali dalam jumlah besar menyebrang Selat Lombok. Setelah perang selesai orang-orang Bali di wilayah kekuasaannya mendirikan beberapa desa yang merupakan kerajaan-kerajaan kecil. Singasari (Karangasem) dengan rajanya A.A Ngurah Made Karangasem pada tahun 1720. Mataram dengan rajanya A.A Bagus Jelantik. Pagesangan dengan rajanya bernama A.A Nyoman Karang. Kerajaan Pagutan dengan rajanya A.A Wayan Sidemen, dan yang terakhir Sengkongo dengan rajanya A.A Ketut Rai (Sejarah Daerah NTB, 1977/78:48).

Kerajaan ini tergabung berdasarkan kekeluargaan. Untuk memperat rasa persaudaraan antar kerajaan pada tahun 1744 didirikan Pura Meru. Di antara kerajaan-kerajaan kecil Singasari di jadikan wakil Karangasem. Singasari berpusat di Cakranegara yang artinya Cakra berarti roda sendangkan Nagara berarti Pemerintahan. Sehingga mulai terbentuklah desa di kawasan Cakranegara.

Kawasan Cakranegara mengalami perubahan ketika Kerajaan Singasari jatuh ketanggan kerajaan Mataram pada tahun 1840 di bawah kepemimpinan dua bersaudara I Gusti Ngurah Ketut Karangasem dan I Gusti Gde Karangasem) (Hoos 1894:203)

Sesudah penentuan pusat kerajaan I Gusti Ngurah Ketut Karangasem memerintahkan untuk pembagunan pola tata ruang kawasan istana menggunakan Asta Bumi seperti masyarakat Hindu pada umumnya. Di pusat lingkaran dibangun puri (istana kerajaan) sebagai tempat tinggal para bangsawan.Sementara di lingkaran berikutnya dibangun perumahanperumahan.Hingga tahun 2015 wilayah Cakranegara merupakan kawasan umat Hindu.

Tapi sungguh sangat disayangkan wilayah Cakranegara yang mendapat pujian karena kerapian, pola tata ruang yang teratur tidak di praktekkan dan di kembangkan lagi baik oleh pemerintah dan para akademik arsitek Lombok. Padahal apabila di kembangkan daerah kumuh dan padat penduduk bisa di kurangi sehingga masyarakat mendapatkan rumah layak huni yang nyaman dan sehat. Kemudian perkembangan kawasan Cakranegara pun tidak bisa dicegah yang dulunya perkampunggan yang tertata rapi sudah mulai berubah menjadi kawasan industry seperti hanlnya toko, perhotelan, mall. Hal ini bila dilihat pembangunan lebih condong 
ke arsitektur luar negri yang meninggalkan ciri khas daerah Cakranegara.

Hal ini berawal dari Gubernur ke 2 NTB Alm. H. R. Warsita Kusuma (68-79) yang mengubah wilayah Cakranegara menjadi wilyah industry dengan jargon memperkuat pondasi dan mempertajam arah pembangunan.Kemudian Gubernur ke4 Warsito (1988-1998) dimana mulai dicanangkan pembangunan Mall dan mengambil lahan tempat pacuan kuda.

Sehingga apa yang biasa kita lihat saat ini ruang publik yang merupakan bagian dari Asta Bumi di ubah menjadi beton modern. Padahal apabila dilihat pola tata kota Cakra mirip dengan tata kota di wilayah Jepang dan India (Funo, 1995). Saat ini masa pemerintahan Gubernur ke-7 TGH. Zainul Majdi serta Walikota Mataram $\mathrm{H}$. Ahyar Abduh bersepakat mengeluarkan Perda kota Mataram No. 12 tahun 2011 dimana inti dari perda itu menyatakan wilayah Cakranegara dijadikan sebagai tempat bisnis dan wilayah industry sehingga banyak oknum melakukan pembelian tanah terhadap rumah-rumah yang beraset budaya menjadi gedung-gedung bertingkat. Rumusan masalah yang akan dibahas dalam penelitian ini adalah: (a) Bagaimana ciri khas Asta Bumi yang berada di Kecamatan Cakranegara?, (b) Bagaimana pandangan masyarakat Hindu di Kecamatan Cakranegara mengenai Asta Bumi?, (c) Bagaimana pandangan akademisi dan pandangan pemerintahan kota Mataram mengenai Asta Bumi di Kecamatan Cakranegara?.

\section{LANDASAN TEORI \\ A. Definisi Asta Bumi}

Asta Bumi dilandasi konsep hubungan harmonis Dwijendra (2010: 1-9) antara lain

1) Bhuana Agung adalah unsur alam semesta

2) Bhuana alit (manusia) merupakan bagian dari alam. Manusia sebagai isi dan alam sebagai wadah, senantiasa dalam keadaan harmonis dan selaras,

3) Manik Ring Capupu yang berarti manikn (janin) dalam cucupu (rahim ibu). Manik ring cupupu memiliki makna tempat yang memberikan kehidupan, perlindungan dan perkembangan janin tersebut, demikian pula halnya manusia berada, hidup berkembang, dan berlindung pada alam semesta.

4) Tri hita karana memiliki arti Tri adalah tiga, Hita berarti kemakmuran baik senang, dan lestari, Karana berarti sebab, sumber, (penyebab). Jadi Tri hita karana adalah setiap wadah kehidupan atau lingkungan buatan yang berusaha diciptakan senilai dengan alam (bhuana agung). Tri Hita Karana memiliki tiga unsure kebaikan, yang meliputi Atma (roh/jiwa), Prana (tenaga), Angga (jasad/fisik),

Konsepsi Tri Hita Karana itu sendiri dipakai dalam pola ruang dan pola perumahan tradisional yang diindentifikasi Parhyangan/Kahyangan Tiga sebagai unsure Atma/jiwa, Krama/warga sebagai unsure Prana tenaga, Palemahan/tanah sebagai unsure Angga/jasad (Ngakan Ketut Acwin Dwijendra, 2010: 2).

Tri Angga memiliki arti, Tri artinya tiga dan Angga berarti badan. Tri Angga ini lebih menekankan pada tiga nilai fisik, yaitu Utama Angga (kepala), Madya Angga (badan), Nista Angga (kaki)

5) Hulu Teben merupakan tata nilai dalam mencapai keselarasan antara Bhuana Agung (alam semesta) dan Bhuana Alit (manusia). Konsep Hulu Teben mempunyai beberapa orientasi-orientasi antara lain: Orientasi dengan konsep sumbu ritual Kangin-Kauh [Kangin (matahari terbit)-luan, nilai utama, Kauh (matahari terbenam)-teba, nilai nista]. Kemudian yang kedua, orientasi dengan konsep sumbu bumi/natural Kaja-Kelod. Kaja (kea rah gunung)-luan, nilai utama serta Kelod (kea rah laut)-teba, nilai nista. Terakhir, orientasi dengan Konsep Akasa-Pertiwi, Atas-Bawah seperti Alam Atas-Akasa, Purusa dan Alam Bawah-Pertiwi, Pradana. Konsep Akasa-Pertiwi ini diterapkan dalam pola ruang kosong dalam perumahan atau lingkungan yang di Bali disebut natah.

6) Sangga Mandala merupakan konsep yan lahir dari Sembilan manifestasi Tuhan, yaitu Dewata Nawa Sanga yang menyebar di delapan arah mata angindi tambah satu di tengah dalam 


\begin{abstract}
menjaga keseimbangan alam semesta.

$\begin{array}{llr}\text { Konsep sangga mandala } & \text { dalam } \\ \text { dijadikan pertimbangan }\end{array}$

penzoningan kegiatan dan tata letak bangunan pada arsitektur taradisional. Seperti kegiatan utama atau yang memerlukan ketenangangan diletakkan di daerah utamaning utama, dan kegiatan yang dianggap kotor diletakkan di daerah nistaning, sedangkan kegiatan diantaranya diletakkan di tengah atau yang kita kenal dengan pola natah.
\end{abstract}

\section{B. Persepektif Sejarah}

Ada beberapa pendapat mengenai pandangan atau penglihatan Sejarah yang diberikan oleh kalangan akademisi, antara lain mendefinisikan Persepektif sejarah menjadi 2 (dua). Persepektif yang pertama adalah persepektif dalam memandang panorama. Persefektif ini membahas adanya perbedaan "kedalaman" objek disebabkan oleh jarak dari tempat memandangnya. Yang jauh tidak hanya kurang jelas countournya, tetapi juga ada perbedaan warnanya.

Seharusnya dalam melihat suatu masa kini kita harus dapat membedakan hal yang lama dan yang baru; jadi, jarak waktunya. Dengan persepektif sejarah memandang sebuah peta, kita perlu "merasakan" perbedaan usia bagianbagiannya serta peta perkembagannya dalam waktu dengan mencerminkan dimensi waktu. Agar pengetahuan fakta-fakta sejarah tidak tertumpuk dalam ingatan kita begitu saja sebagai suatu agresi, maka perlu ada penstrukturan berdasarkan persepektif sejarah..

Persepektif ke dua adalah pandangan sejarah yang melihat masa kini tidak terlepas dari masa lampau dan identitasnya. Sebaliknya, gambaran masa lampau ditentukan oleh pandagan masa kini. Di sini yang kita hadapi bukan lingkaran sepihak masa lampau saja atau masa depan saja tetapi dua pandagan yang saling melengkapi. Pandagan masa kini mengarahkan seleksi dan penyorotan gejala berdasarkan jiwa zaman, sedang yang kedua tidak dapat melihat masa kini sebagai sesuatu dalam pemisahan. Persepektif historis mempunyai dua dimensi aspek masa kini; dan aspek masa lampau.
Implikasi metodologisnya bukanlah naratif yang diutamakan melainkan polapola, struktur, tendensi, konjunktur. Persepektif sejarah senantiasa menempatkan suatu gejala dalam setting historis; suatu struktur situasional yang didalamnya terjadi gejala sejarah yang dikaji. Dengan mengalokasikannya sebagai fakta sejarah dengan sendirinya tampil lingkungan sosialnya beserta segala macam unsur kultural serta pengaruhnya pada gejala itu. Akan menjadi jelas kondisi dimana hal itu terjadi, maka akan terjadi proses menemukan fakta. Bila dilihat apabila suatu gejala dikembalikkan dalam setting historisnya akan tampak ikatan waktunya menjadi suatu fakta.

Jadi, dapat disimpulkan persepektif sejarah merupakan suatu pandangan yang berkenaan dengan kehidupan manusia baik aktivitas, dan gerak kehidupannya yang mempengaruhi kehidupan manusia lainnya.

\section{Konsep dan Manfaat Tata Ruang Bagi Kebudayaan Masyarakat}

Tarigan (2008: 10 ) konsep tata ruang bagi kebudayaan masyarakat yaitu konsep tata guna tanah dimana pemanfaatan lokasi yang tepat seperti lokasi pemerintahan, wahana terbuka, perdagangan teratur rapi sehingga dapat keteraturan dalam keseimbangan perekonomian dan dalam hal pengaturan kebijakan

Manfaat tata ruang bagi kebudayaan masyarakat. Pertama dapat membantu atau memandu para pelaku ekonomi untuk memilih kegiatan apa yang perlu dikembangkan di masa yang akan datang dan dimana lokasi kegiatan seperti itumasih di izinkan.

Ke dua, Lokasi sendiri dapat dipergunakan untuk berbagai kegiatan, penetapan kegiatan tertentupada lokasi tertentu yang akan member nilai tambah maksimal bagi masyarakat

Manfaat dari tata ruang bagi kebudayaan itu sendiri yaitu mendukung kepariwisataan dimana tata kota akan menjadi ciri khas yang dimiliki suatu kota yang akan menarik peminat wisatawan local maupun mancanegara datang berkunjung (Budiharjo (2009: 184).

Kesimpulannya, tata ruang bagi kebudayaan masyarakat baik itu manfaat maupun konsep. Tata kota memiliki arti 
dalam menciptakan ciri khas suatu daerah, serta keteraturan dalam menaruh kebijakan ketika kota tertata.

\section{METODE PENELITIAN \\ A. Jenis dan Pendekatan Penelitian}

Jenis penelitian ini adalah penelitian historis dengan pendekatan kualitatif, yaitu data yang berbentuk gambar, kata atau kalimat. Dalam penelitian ini, jenis penelitian yang digunakan yaitu penelitian historis dengan pendekatan kualitatif yaitu suatu metode penelitian yang dalam membahas, permasalahan dengan berpedoman pada literature-literatur yang ada kaitannya dengn masalah yang diteliti yaitu Asta Bumi dalam Persepektif Sejarah (Studi Kasus Tata Kota Kecamatan Cakranegara Kota Mataram Provinsi NTB)

\section{B. Teknik Pengumpulan Data}

Teknik pengumpulan data yang digunakan dalam penelitian ini meliputi beberapa kegiatan, adapun kegiatannya adalah sebagai berikut:

a. Heuristik

Heurstik adalah suatu teknik, suatu seni, dan bukan suatu ilmu. Oleh karena itu, 68erminolo tidak mempunyai peraturan-peraturan umum. Heuristik sering kali merupakan suatu keterampilan dalam menemukan, mengenai dan memperinci bibiliografi, atau mengklasifikasi dan merawat catatan-catatan (G. J. Renier dalam Abdurrahman, 20011:104).

Maka sebelum mengalami yang terkhir ini, harus lebih dahulu menggunakan kemampaun pikiran unutk mengatur strategi: dimana dan bagaimana akan mendapatkan bahanbahan tersebut; siapa-siapa atau instansi apa yang dapat dihubungi, berapa biaya yang harus dikeluarkan untuk perjalanan, akomodasi kalau ketempat-tempat lain, unutk fotokop, informan, dan lain-lain (Sjamsuddin, 2012:67-68)

b. Observasi

Observasi merupakan salah satu teknik yang paling banyak dilakukan dalam penelitian, baik kualitatif maupun kuantitatif, baik social maupun umaniora. Dalam etnografi teknik observasi dikategorikan sebagai aliran utama (Rhatna Khuta, 2010:217).

c. Teknik Wawancara

Wawancara (interview) adalah cara-cara memperoleh data dengan berhadapan langsung, bercakap-cakap, baik antar individu dengan individu maupun individu dengan kelompok (Ratna Khuta,2010: 222)

d. Dokumentasi

teknik-teknik dokumentasi yaitu mencari data mengenai hal-hal atau variable yang berupa catatan, transkip, buku, surat kabar, majalah, prasasti, notulen rapat, lengger, agenda, dan sebagainya (Arikunto, 2010: 274).

Penelitian ini juga menggunakan teknik dokumentasi yang berupa referensi tertulis, foto-foto dan observasi secara langsung karena kajian utama pada penelitian ini menitik beratkan pada "Asta Bumi dalam Persefektif Sejarah (Studi Kasus Tata Kota Kecamatan Cakranegara Kota Mataram Provinsi NTB)"

e. Kritik

Teknik pengumpulan data dengan menggunakan langkah kritik, hal-hal yang dilakukan adalah untuk mencari otentitas, integritas dan kredebelitas sumber dengan cara meneliti setiap sumber dan membandingkannya, bukan hanya mengacu pada satu sumber saja tetapi lebih. Hal tersebut dimaksudkan untuk mendapat hasil yang maksimal dalam membandingkan antara sumber yang satu dengan yang lainnya.

1. Kritik Ekternal

Saksi mata atau penulis tersebut harus diketahui sebagai orang yang dapat dipercayai (credible). Kesaksian (testimony) itu sendiri harus dapat dipahami dengan jelas. Pemeriksaan yang ketat ini mempunyai 68ermino yang kuat sehubungan dengan beberapa sumber telah dibuktikan palsu; dalam penelitian (investigasi) yang dilakukan telah ditemukan bahwa sumber-sumber itu telah dipalsu atau dibuat-buat. Beberapa sumber lain meskipun asli, ternyata dengan 
berbagai 69ermino telah memberikan kesaksian-kesaksian yang tidak dapat diandalakan (Lucey dan Gee dalam Sjamsuddin, 2012: 104).

Berdasarkan pendapat tokoh tersebut peneliti dapat menjelaskan bahwa dalam penelitian ini untuk mencari ontensitas sumber, hal-hal yang dapat dilakukan adalah dengan cara melihat gaya bahasa, ejaan, tahun terbit, dan huruf yang digunakan, ini hanya dilakukan pada sumbersumber yang diambil dari beberapa sumber tertulis atau literature yang ada, terutama yang relevan dengan objek yang akan dikaji dalam penelitian ini. Beberapa sumber tersebut menunjukkan keotentit asannya karena dikarang oleh beberapa orang yang berasal dari beberapa daerah yang masih berada didalam lingkup pulau Lombok.

2. Kritik Internal eksternal, Kebalikan dari kritik sebagaimana yang disarankan oleh istilahnya menekankan aspek dalam yaitu isi dari sumber kesaksian (testimony). Setelah fakta kesaksian ditegakkan melalui kritik eksternal, tiba giliran sejarawan untuk mengadakan evaluasi terhadap kesaksian itu. la harus memutuskan apakah kesaksian itu dapat diandalkan atau tidak. Keputusan ini didasarkan atas penemuan dua penyidikan (inkuiri), (Lucey dan Gee dalam Sjamsuddin, 2012: 112).

Pandangan tokoh tersebut menjadi pedoman bagi peneliti dan memberikan penjelasan bahwa untuk menentukan beberapa sumber yang relevan dengan objek kajian pada penelitian ini, bahwa didalam buku antara buku yang dikarang oleh Ngakan Ketut Acwin Dwijendra tentang Asta Bumi dengan buku karangan Prof. Dr. Azyumardi, M. A. tentang Semerbak Dupa di Pulau Seribu Masjid dan informasi yang diperoleh dari informan dan responden pada observasi awal terdapat kesamaan persepsi.

f. Interpretasi

$$
\text { Dalam penelitian sejarah, }
$$

digunakan secara bersamaan tiga bentuk teknis dasar tulis-menulis yaitu deskripsi, narasi, dan analisis.ketika sejarawan menulis sebenarnya merupakan keiginannya untuk menjelaskan (eksplanasi) sejarah, ada dua dorongan utama yang menggerakannya yakni mencipta ulang dan menafsirkan (interpretasi). Dorongan pertama menuntut deskripsi dan narasi, sedangkan dorongan kedua menuntut analisis (Tosh dalam Sjamsuddin, 2012: 123).

Interpretasi atau penafsiran sejarah seringkali disebut juga dengan analisis sejarah. Analisis sendiri berarti menguraikan dan secara 69erminology berbeda dengan sintesis yang berarti menyatukan. Namun keduanya, analisis dan sintesis dipandang sebagai metodemetode utama dalam interpretasi (Kuntowijoyo dalam Abdurrahman, 2011: 114).

$\begin{array}{llr} & \text { Berdasarkan pandagan } \\ \text { tersebut dapat dijeelaskan } & \text { bahwa } \\ \text { interpretasi } & \text { merupakan } & \text { cara } \\ \text { menganalisis, } & \text { menguraikan } & \text { serta }\end{array}$ menyentuh sejarah berdasarkan sumber-sumber yang ada sehingga dapat melahirkan deskripsi dan narasi yang lebih kompleks.

g. Historiografi

Pada tahap ini peneliti menuliskan Asta Bumi dalam Persefektif Sejarah (Studi Kasus Tata Kota Kecamatan Cakranegara Kota Mataram Provinsi NTB) berdasarkan sumbersumber yang diperoleh baik itu berupa sumber primer maupun sumber sekunder serta sumber lain yang relevan dengan penelitian ini. Hal-hal yang sangat diperhatikan didalam system penulisan pada pnelitian ini adalah tentang sistematika penulisan, bahasa yang akan digunakan, serta kronologis sejarah mengenai objek yang akan diteliti guna memperoleh hasil penulisan yang ilmiah serta dapat dipertanggung jawabkan keasliannya. 


\section{Analisis Data}

Analisis data kualitatif dijelaskan dalam Miles dan Hiberman (1992: 16) sebagai berikut:

\section{Reduksi Data}

Reduksi data merupakan suatu bentuk analisis yang menajamkan, menggolongkan, mengarahkan, membuang yang tidak perlu, dan mengorganisasikan data dengan cara sedemikian rupa hingga kesimpulan finalnya dapat ditarik atau diverifikasi. Reduksi data juga dapat berupa proses pemilihan, pemusatan perhatian pada penyederhanaan, pengabstrakan, dan transportasi data kasar yang muncul dari catatan-catatan tertulis dilapangan. Data yang akan diambil adalah mengenai Asta Bumi dalam Persefektif Sejarah (Studi Kasus Tata Kota Kecamatan Cakranegara Kota Mataram).

2. Penyajian Data

$$
\text { Penyajian data adalah }
$$
sekumpulan data informasi tersusun yang member kemungkinan adanya penarikan kesimpulan dan pengambilan tindakan yang dapat dilakukan dalam berbagai bentuk table, grafik, dan juga akan dilakukan dalam bentuk uraian singkat, bagan, serta teks naratif.

Menurut Miles dan Huberman dalam Sugiono penelitian kualitatif, penyajian data dapat dilakukan dengan mendisplaykan data, maka akan memudahkan untuk memahami apa yang terjadi, merencanakan kerja selanjutnya berdasarkan apa yang telah dipahami tersebut. Melihat penampilan yang membantu kita untuk memahami apa yang terjadi dan melakukan pemahaman dengan hati-hati dengan beberapa hal analisa lebih lanjut. (Sugiono, 2014: 341)

3. Menarik kesimpulan
Langkah ketiga dalam analisa data kualitatif adalah menarik kesimpuln, kesimpulan dalam penelitian kualitatif adalah proses menemukan makna data yang bertujuan memahami tafsiran dalam konteknya dengan secara keseluruhan, temuan tersebut dapat berupa deskripsi atau gambaran suatu objek secara jelas.

\section{HASIL DAN PEMBAHASAN}

A. Ciri Khas Asta Bumi yang Berada di Kecamatan Cakranegara

Cakranegara merupakan kota koloni dari kerajaan Karang Asem yang terletak di sebelah timur pulau Bali. Ide dari bentuk kota tersebut berdasarkan kota Hindu Bali adalah seorang punggawa Gede, pola fisik kawasan ini berbentuk sistem grid atau yang sering di sebut karang.. Pada awalnya Cakranegara dibangun dengan 33 unit karang. Setiap karang tidak harus mempunyai pura. Pusat terbesar dan termegah dari kuil hindu adalah pura Meru, kemudian disusul dengan pura mayura. Pura Meru dibangun tahun 1720 oleh raja Karangasem, Agung Made ngurah kepada unit kerajaan kecil Bali di Lombok. Pura ini dipersembahaka ke Brahma, Wishnu, dan Siwa. Jumlah angka 33 unit karang ini berhubungan dengan suatu bilangan khusus dalam konteks agama Hindu.

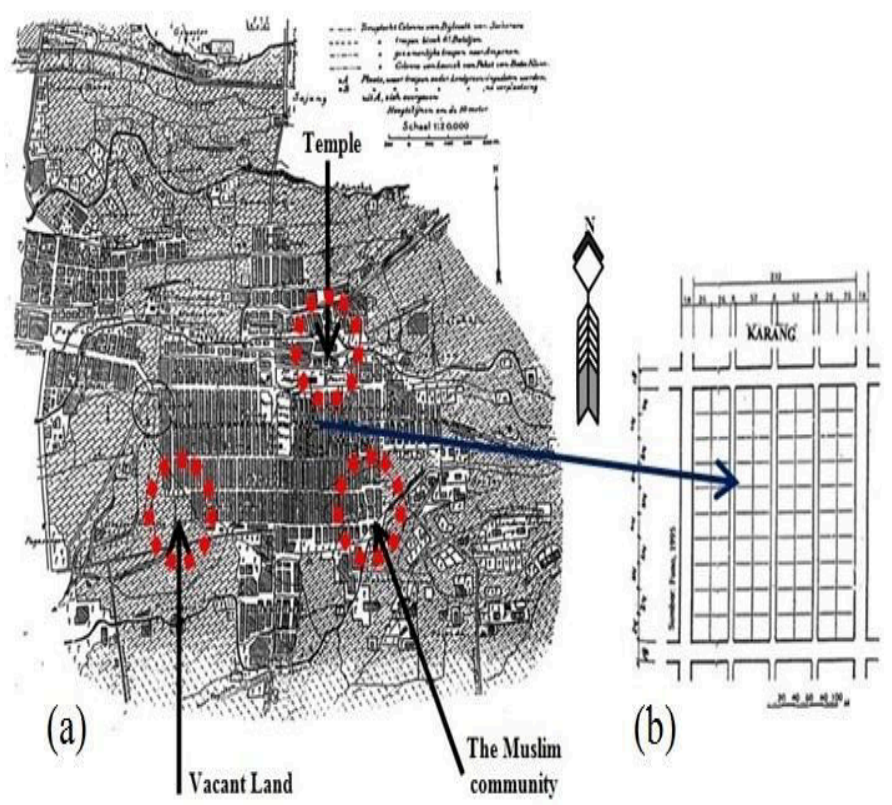
Gambar 1. (a) Peta daerah Cakranegara dan (b) grid (block) kawasan Cakranegara (a) Cool (1896), (b) Funo (1995) 
Cakranegara merupakan pusat pemerintahan kerajaan Karangasem. Dimana kasta tertinggi di dalam susunan sosial semakin dekat dengan istana (wawancara dengan $\mathrm{Bu}$ Evi 20 agustus 2015). Banyak perubahan yang terjadi Cakranegara. Ini bisa di lihat dengan kedatangan Belanda, Orde lama, dan Orde Baru. Di lihat dari zaman kekuasaan Belanda, Belanda pada saat itu memindahkan pusat pemerintahan yang dulunya berpusat di Cakranegara dipindahkan ke kawasan Mataram. Hal ini dikarenakan sudah mengakarnya para ningrat di Cakra. Selain itu di Cakra di bangun tempat hiburan pacuan kuda untuk masyarakat (Mataram Mall) serta bank pemerintah untuk kontrol keuangan. Pada umumnya Cina/Tionghoa sudah mulai di ijinkan masuk, tetapi pada tahun 1965 setelah terjadinya pengusiran etnis Tionghoa/Cina dari Lombok Timur, para pengungsi di tempatkan di Cakranegara. Sejak mulai pada saat itu etnis tionghoa mulai menetap dan hal ini di dukung karena masyarakat Bali Gemar berjudi sabuk ayam dan menjual tanahnya pada saat itu. Pada awal orde Baru Cakranegara pak walikota Mujitahid menata wilayah Cakranegara menjadi pusat perdaganggan seperti terminal (hotel mataram plaza) serta perpindahan pelabuhan Ampenan ke Lembar.

Pola ruang dan perumahan menggunakan Filsuf asta bumi pada masyarakat penganut agama hindu sangat terkait dengan sikap dan pandagan hidup masyarakat hindu, tidak terlepas dari sendisendi agama, adat istiadat, kepercayaan dan sistem religi yang melandasi aspekaspek kehidupan. Peranan dan pengaruh Agama Hindu dalam penataan lingkungan buatan, yaitu terjadinya implikasi agama, dengan berbagai kehidupan bermasyarakat. Agama Hindu mengajarkan agar manusia mengharmoniskan alam semesta dengan segala isinya yakni buana agung (makrokosmos), dengan bhuana alit (mikro kosmos), dalam kaitan ini bhuana agung adalah lingkungan buatan/bangunan dan bhuana alit adalah manusia yang mendirikan dan menggunakan wadah tersebut (dikutip ngakan budi dwijendra, Subandi, 1990).

Untuk menyelaraskan antara bhuana agung/alam semesta dengan bhuna alit/manusia, maka setiap lingkungan kehidupan kawasan Cakranegara di buat senilai dengan bhuana agung dengan unsur-unsur yang utuh yakni Tri Hita Karana. Tri Hita Karana memiliki makna Tri berarti tiga, Hita berarti kemakmuran, baik gembira, senang dan lestari. Sedangkan Karana berarti sebab, sumber (penyebab). Jadi Tri Hita Karana berarti tiga unsur penyebab kebaikan, yang meliputi : Atma (roh), Prana (Tenaga), Angga (jasad/fisik). Konsepsi Asta Bumi berdasarkan Tri Hita Karana melandasi terwujudnya susunan kosmos dari yang paling makro (bhuana agung/alam semesta) sampai hal yang paling mikro (bhuana alit/manusia).

Dalam alam semesta jiwa adalah paramatma (Tuhan yang Maha Esa), tenaga adalah berbagai tenaga alam dan jasad adalah Panca Maha Bhuta. Dalam perumahan (tingkat desa), jiwa adalah prhyangan (pura desa), tenaga adalah pawongan (masyarakat) dan jasad adalah . Dalam perumahan (tingkat desa), jiwa adalah prhyangan (pura desa), tenaga adalah pawongan (masyarakat) dan jasad adalah palemahan (wilayah desa). Demikian pula halnya dalam banjar, jiwa adalah prhyangan (pura banjar), tenaga adalah pawongan (warga banjar) dan jasad adalah palemahan (wilayah banjar). Pada rumah tinggal jiwa adalah sanggah pemerajan (tempat suci), tenaga adalah penghuni dan jasad adalah perkarangan. Sedangkan pada manusia, jiwa adalah atman, tenaga adalah sabda bayu idep dan jasad adalah stula sarira/tubuh manusia.

Tri Hita Karana (tiga unsur kehidupan) yang mengatur keseimbangan manusia dengan alam yang mengatur keseimbangan manusia dengan alam, tersusun dalam susunan jasad atau angga yang memberikan turunan konsep ruang yang disebut Tri Angga. Tri Angga memiliki arti, Tri berarti tiga, Angga berarti badan, dimana Tri Angga ini lebih menekankan pada tiga nilai fisik Utama Angga (kepala), Madya Angga (badan) dan Nista Angga (kaki).

Konsep Tri Angga ini dalam bhuana agung disebut dengan Tri Loka atau disebut Tri Mandala. Konsepsi Tri Angga ini berlaku dari yang bersifat makro sampai yang paling mikro. Ketiga konsep dari tata nilai tersebut jika didasarkan secara vertikal, maka nilai utama berada pada posisi teratas sacral, 
madya pada posisi tengah, dan terakhir

Nsta pada posisi terendah/kotor.

Tabel 1

\begin{tabular}{cccc}
\hline Unsur & Utama Angga & Madya Angga & Nista Angga \\
\hline Alam Semesta & Swah loka & Bhuana loka & Bhur Loka \\
Wilayah & Gunung & Daratan & Laut \\
Perumahan & Kahyangan tiga & Pemukiman & Setra/kuburan \\
Rumah & Sanggah/peme & Tegak umah & Tebe \\
Tinggal & rajaan & Badan & Kaki \\
Manusia & Kepala & Bala
\end{tabular}

Hal ini bisa di lihat dari pembentukan struktur tata kota di Cakranegara Utama Angga perumahan Angga yaitu Sanggah (Pura Meru dan Pura Mayura), kemudian pemukiman yang dimaksud Cakranegara, dan yang terakhir Nista Angga (pantai Ampenan)

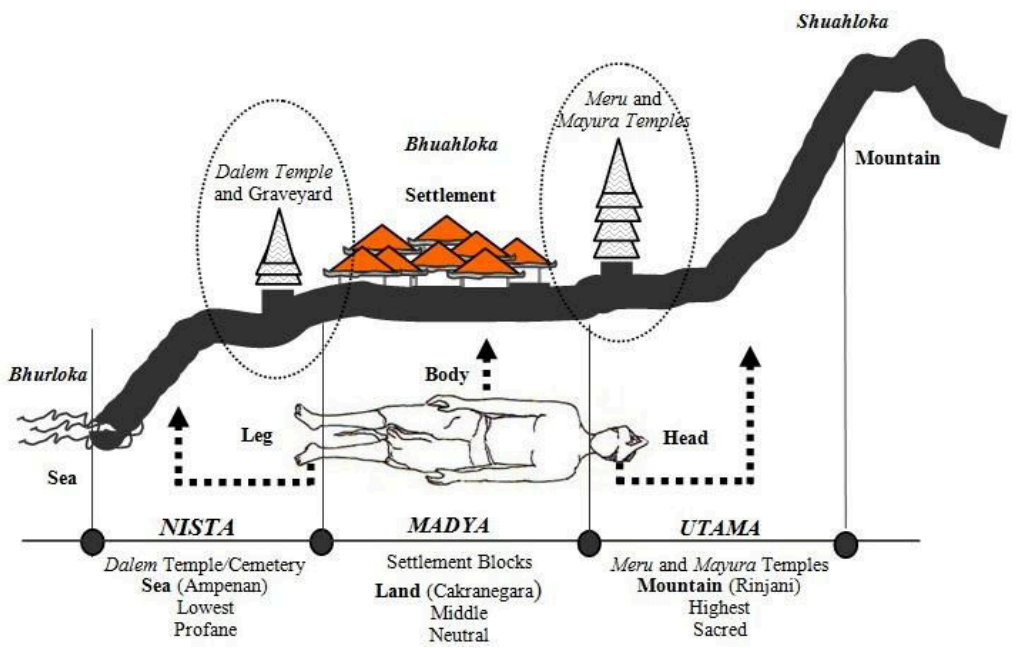

Gambar 2. Konsep Tri Angga; Tri Mandala; and Tri Loka (Mulyadi (2008))

Selain memberikan nilai secara vertikal, Tri Angga juga memiliki tata nilai Hulu-Teben, yang merupakan tata nilai dalam mencapai keselarasan antara bhuana agung/alam semesta dan Bhuana Alit/manusia. Konsep Hulu Teben yang digunakan di kawasan Cakranegara ini kemudian mempunyai beberapa orientasiorientasi antara lain :

1) Orientasi dengan konsep sumbu ritual Kangin-Kauh

a. Kangin (matahari terbit)-luan, nilai utama.

b. Kauh (matahari terbenam), teba, nilai nista

2) Orientasi dengan konsep sumbu bumi/natural kaja-kelod
a. Kaja (ke arah gunung)-luan, nilai utama.
b. Kelod (ke arah laut)-teba, nilai nista.

3) Orientasi dengan Konsep Akasa-Pertiwi, Atas-Bawah

a. Alam atas-Akassa, Purusua

b. Alam bawah-Pertiwi Pradana.

Penggabungan konsep sumbu bumi (Kaja-Kelod) dengan konsep sumbu ritual menghasilkan konsep Sangan Mandala. Konsep tata ruang Sanga mandala juga merupakan konsep yang lahir dari sembilan manifestasi Tuhan, yaitu Dewata Nawa Sanga yang menyebar di delapan arah mata angin di tambah satu dengan di tengah dalam menjaga keseimbangan alam semesta.

Konsep Sanga Mandala ini menjadi pertimbangan dalam penzioningan kegiatan dan tata letak bangunan pada asitektur tata kota di Cakranegara. Kegiatan utama atau yang memerlukan ketenangan diletakkan di daerah Utamaning Utama, dan kegiatan yang dianggap kotor diletakkan di daerah 
Nistaning Nista, sedangkan kegiatan di antaranya diletakkan di tengah (Natah).

Dalam skala perumahan (desa) konsep Sanga Mandala, menempatkan kegiatan yang bersifat suci (pura desa) pada daerah utamaning utama (kaja-kangin), letak pura Dalem dan kuburan pada daerah nisthaning nista (klod kauh), dan pemukiman pada daerah madya, ini terutama terlihat pada perumahan yang memilki pola perempatan.

Rumah yang menganut Asta bumi memiliki beberapa bagian seperti Sanggah, Bale Dangin, Bale delod, Paon, Bale Dauh dan Meten. Dilihat dari kedudukannya dalam Sangga Mandala, natah berlokasi di zona Madyaning-Madya, suatu zona yang berada di tengah-tengah yang merupakan pusat dari Sangga Mandala. Sehingga natah merupakan pusat aktifitas manusia

Natah Sanggah terletak pada zona Kaja-Dangin yaitu di tengah-tengah Sanggah. Natah Bale terletak ditengahtengah umah dan Natah Paon terletak di depan Paon dan Natah. Penunggun Karang terletak di Kaja-Kauh (barat laut), sesuai dengan letak Penunggun Karang.

Dilihat dari aspek simbolik pada perumahan yang berkaitan dengan kosmologi. Kegiatan masyarakat Cakranegara berkaitangan dengan relegius maupun sosial. Hal inipun di wujudkan dalam penentuan lokasi bangunan di pekarangan rumah. Orientasi arah sakral tersebut seperti:

a. Ke arah gunung Rinjani yang merupakan tempat tertinggi di kawasan Lombok

b. Sumbu jalan (kaja-kelod) yang menuju ke dunia leluhur yang bersemayam di gunung

Untuk di rumah sendiri nilai kesakralan terdapat nilai kesakralan masing-masing, seperti: Sanggah (Pura rumah tangga), Pengijeng, Bale Adat, Meten (tempat tidur), Bale (ruang serba guna), Pawon (dapur), Jineng (lumbung), Kandang ternak, Teben (halaman belakang).

\section{B. Pandagan Masyarakat Hindu Tentang Asta Bumi \\ Menurut data kependudukan} dominasi pemeluk agama Hindu di Cakranegara masih tertinggi ke dua dengan jumlah 20.020 jiwa. Dengan perkembangan kawasan Cakranegara yang dulunya masyarakat Hindu merupakan mayoritas. Masyarakat Hindu mulai berkurang baik itu karena jual beli tanah, fungsi hunian dan komersial, terjadinya urbanisasi (desa ke kota) maupun program pemerintah trnasmigrasi yang dulunya Lombok merupakan penduduk jarang, sehingga wilayah seperti Jawa bertransmigrasi ke Lombok dan bertempat tinggal di Lombok terutama kawasan Cakranegara. Walaupun agama pemeluk agama Hindu di Cakranegara mulai berkuran masih banyak yang memeperthankan konsep asta bumi seperti kutipan wawancara berikut:

Asta bumi dan asta kosala-kosali sudah tercantum di dalam kitab Rwa Binneda. Di dalam kitab tersebut tercantum bagaimana tata cara pembentukan suatu rumah, karang. Seperti halnya kalau perumahan letak tempat ibadah, dapur rumah utama, tempat berkumpul. Kemudian kalau karang letak pemakaman, pura utama, pura desa seta pemukiman (natah). (Wawancara dengan Bapak I Made Wirawan. 10 Agustus 2015).

Mengenai ciri-ciri asta bumi yang digunakan kerajaan Karangasem sebagai pondasi tata kota pembangunan di kawasan Cakranegara memiliki perbedaan dengan kawasan adat di Bali. Bali jarak jalan tidak seluas di Lombok. Dan pura di kawasan Karang di Cakra tidak selamanya ada. Sedangkan di Bali yang kita tahu setiap Karang ada pura. Pola gridnya pun berbeda dimana setiap karang bila mayoritas pemeluk agama Hindu ada minoritas pemeluk agama Islam begitupun sebaliknya.

Apabila kita bandingkan dengan kawasan Cakranegara dengan daerah Bali. Setiap karang di kawasan Bali di wajibkan setiap karang memilki pura dan pemakaman. Beda halnya dengan di kawasan Cakranegara setiap karang tidak di wajibkan memiliki pura di setiap karang. Kemudian bisa di kawasan Bali untuk jalan tidak begitu lebar dan tidak sama di setiap karangnya berbeda dengan di kawasan Cakranegara. Cakranegara memilki jalan setiap karang memiliki persamaan ukuran dan jalan utama yang lebar.

Kemudian dalam setiap pengairan air limbah (got) selalu terairi dengan dengan air hal ini dikarenakan kawasan taman mayura 
yang memiliki mata air dan sistem pengairan di taman tersebut. Sehingga tidak mengakibatkan banjir yang sampai merendam rumah.

Walaupun masyrakat pemeluk agama Hindu di kawasan Cakranegara menjunjung tinggi ajaran agama Hindu seperti halnya Asta Bumi dalam pemabangunan rumah dan karang (wilayah). Tetapi dengan berkembangnya zaman terutama kawasan Cakranegra di jadikan sebagai tempat bisnis serta kawasan budaya. Berakibat harga tanah menjadi naik. Sehingga memilih perkarangan yang minimalis seperti PERUMNAS maupun BTN. Faktor ke dua yaitu dalam satu perkarangan rumah keluarga sudah memilki anak dan dan cucu. Sehingga tidak memungkinkan tinggal di rumah tersebut dan pindah.Unuk penggunaan Asta bumi sangat bermanfaat dan dianjurkan bagi umat hidup karena merupakan keselarasan kami dengan alam. Tetapi dengan perkembangan zaman Asta bumi mulai agak di tinggalkan terutama masalah luas perkarangan serta mahalnya tanah sehingga anak cucu tidak bisa tinggal lagi. Dan pindah ke perkarangan yang baru seperti BTN. Seperti halnya hasil wawancara berikut:

Dulu sewaktu saya kecil rumahrumah di Cakra perkarangannya luas-luas. Sehingga kami mudah bermain dan ruang terbuka pun masih ada. Tapi sayang sekarang Cakra mulai dirasa padat. Rumahrumah yang menganut Asta Bumi sudah mulai meninggalkan. Tetapi posisi tempat ibadah dan paon tetap utara selatan hanya luas perkarangan, tepat pertemuan, anak-anak, dan orang tua digabung dalam bale natah. (Wawancara dengan bapak I Gde Mintar Yogastawa 13 Agustus 2015).

Untuk bahan material yang digunakan dalam proses pembangunan tidak semabrang karena apabila melakukan pelanggran akan mendatangkan musibah, penyakit, pendek umur. Seperti Bramasesa (tidak boleh menggunakan bahan material sisa kebakaran), Nguringwapke (memakai bekas bahan bangunan yang rubuh tanpa sebab yang jelas), Poman Pamali (menggunakan kayu yang berada di jurang), Anepiluwah (menggunakan kayu yang berada di tepi sungai), Sesawadung (memakai kayu sisa dari tebangan terdahulu), Candragni (memakai kayu yang berada di tempat ibadah keluarga), bhutagraha (kayu yang diambil di kuburan), Pamali Wates (mengambil kayu di tengah pembatas perkaangan), Asurigrha (kayu yang diambil dari tepi danau), Bhutangandang (kayu yang diambil dari pohon yang melintang di jalan), Ngayut Dana (pohon yang diambil dari aliran sungai), Sinarbegelap (kayu yang diambil dari pohon yang tumbang akibat sambaran petir).

\section{Pandangan Akademisi dan Pemerintahan tentang Asta bumi}

Asta Bumi yang digunakan untuk mengatur lokasi baik dalam lingkungan perumahan maupun karang di kawasan Cakanegara mendapat perhatian khusus dari beberapa akademisi maupun pemerintahan baik dari segi sistem pembagian lokasi pembangunan pemukiman, pura (tempat ibadah), pasar, jalan. Dikarenakan kawasan memiliki pola ruang berupa grid seperti papan yang teratur seperti halnya kutipan wawancara berikut:

Dari lingkungan akademisi sendiri memiliki pendapat sendiri mengenai tata kota di kawasan Cakranegara. Seperti kutipan wawancara berikut

Cakranegara memiliki
dasar/pondasi kota yang bagus
dimana setiap rumah tertata rapi
serta luas jalan baik di karang
maupun jalan utama sangat lebar.
Hal ini mempercantik kawasan
Cakranegara sebagai kawasan
bisnis dan budaya (Wawancara
dengan lbu Evi 20 Agustus 2015).

Kawasan Cakranegara memiliki pondasi yang kuat terutama di pusat Cakranegara walau di Cakranegara Utara mengalami perubahan dari yang dulunya perumahan Bali sekarang menjadi pertokoan. Tapi tidak bisa mengubah pola tata ruang yang sudah ada. Ini sudah di lihat dari satelit dimana kawasan memiliki grid yang teratur. Dari sistem pengairan atau 
pembuangan limbahnhya sendiri selalu di aliri air. Hal ini bisa dilihat di kawasan Taman Mayura. Sehingga dampak banjir bisa di tanggulangi.

Cakranegara dulunya merupakan pusat pemerintah Kerajaan Karangasem. Kawasan ini telah mengalami beberapa fase dari segi pembangunan, baik jaman Karangasem sendiri, pemerintah Belanda, Jepang Orde lama, baru dan sampai jaman reformasi. Seperti perubahan-perubahan yang terjadi bisa dilihat Mataram Mall yang dulunya adalah tempat pacuan kuda serta. Perempatan Cakra yang dulunya adalah terminal

Sedangkan awal dari pembangunan kawasan cakra ini, salah satunya di kutip dari pernyataan sejarawan lombok Ahmad JD, seperti berikut:

\section{Cakranegara merupakan bahasa Sansekerta dari kata Cakra dan Negara yang berarti Lingkaran/Roda pemerintahan yang berpusat dulunya di Taman Mayura sekarang. Arsitektur tata kota kawasan Cakra ini pun d prakarsai oleh Ide Bagus Gede atau yang sering disebut Punggawa Gede. Tujuan dari lingkaran tata kota ini untuk sistem benteng pertahanan. Hal ini bisa dilihat tumpulnya kekuatan dari serangan Belanda waktu tahun 1894. Punggawa Gede pun belajar arsitektur ini langsung ke Prancis dan jepara. (Wawancara dengan Miq Jde tanggal 25 Agustus 2015)}

Bila dilihat pernyataan-pernyataan ke dua narasumber. Kawasan Cakra selain di bangun sebagai tempat tinggal masyarakat Bali (Hindu) juga sebagai tempat pemerintahan dan benteng pertahanan kerajaan. Kawasa Cakranegara pun sudah mengalami beberapa perubahan di Jaman pemerintahan Belanda pusat pemerintahan di pindahkan ke Mataram dan di bangunnya pusat hiburan pacuan kuda, sedangkan pada jaman orde lama dan baru kawasan cakra pun di jadikan tempat perdaganggan hal ini di dukung datangnya etnis tionghoa yang bernaluri dagang. Sedangkan pada tahun 2011 Cakra pun di jadikan sebagai tempat bisnis dan budaya.

\section{Pandangan Pemerintah}

Cakranegara merupakan kawasan pusat bisnis dan budaya salah satu pemasukan kas daerah. Sehingga Cakranegara menjadi salah satu perhatian khusus pemerintah kota Mataram salah satunya bisa dilihat dengan di tetapkannya ketetapan Peraturan Daerah Kota Mataram No 12 Tahun 2012. Di dalam hal budaya pemerintah memiliki pandangan tersendiri seperti kutipan wawancara berikut:

Struktur dasar tata kota Cakra sangat unik. Mengabungkan filosofi dari Hindu seperti Asta Bumi dan Islam. Yang notabene terjadi keserasian antar umat beragama. Bisa kita lihat Pura Meru dan masjid di belakang pura serta pola tata ruang seperti pola papan catur misalkan kuning Hindu dan putih Islam sehinga saling berdekatan satu sama lain. Sehingga tercipta keselarasan antar umat beragama. Seperti acara begawe dan lain-lain. (Wawancara, dengan bapak $\mathrm{H}$. Lalu Bahtiar, 28 Agustus 2015).

Dengan adanya ciri khas di kawasan Cakranegaa, dapat memperkuat kunjungan wisata lokal serta luar negri baik dalam kegiatan wisata atau liburan bahkan riset. $\mathrm{Hal}$ ini sudah dilakukan oleh peneliti Jepang Funo yang berpendapat kawasan Cakranegara memiliki ciri khusus dan perlu di contoh dalam sistem pembangunan kota. Serta adanya kemiripan kawasan Cakranegara dengan tata kota di jepang dan India dalam penggunaan grid.

Tapi dengan seiring perkembangan kawasan Cakranegara. Kota yang tertata rapi memiliki beberapa kendala dimana jumlah yang memilki kendaraan pribadi mulai meningkat dan got yang sudah dari dulu di buat tidak memungkinkan lagi sehingga terjadi perbaikan seperti jalan Ahmad Yani dan perbaikan gorong agar tidak terjadi kemacetan berkepanjangan serta banjir. Untuk pejalan kaki sudah mulai tertata terutama dari kawasan Mataram Mall sampai perempatan Cakra. Untuk tempat parkir sudah mulai ada pengalihan walaupun masih ada yang menggunakan jalan sebagai tempat parkit. 
E. Pembahasan

1. Ciri Khas Asta Bumi

Seperti yang sudah di jelaskan sebelumnya. Asta Bumi merupakan fingshui masyarakat Hindu Bali. Dimana dalam pengaturan tata letak bangunan, tempat ibadah, dapur, dalam perkarangan rumah. Kemudian untuk desa pengaturan letak Pura Pusat, pemukiman dan pemakaman. Asta Bumi ini sendiri menggunakan Konsep Tri Hita Karana, Tri Angga, Tri loka, Hulu Teben serta Sangga mandala. Ciri khas yang digunakan di Kawasan Cakranegara sangat terkait dengan Teori Max Weber Rasionalitas Berorientasi Nilai hal ini bisa kita lihat dari nilai penggunaan letak Asta bumi yang dipercaya.
Sebelum pembangunan suatu perumahan maupun karang harus memerhatikan keseimbangan alam (makrokosmos) dan manusia (mikrokosmos). Agar terjadi keselarasan antara alam dan manusia. Kemudian untuk letak arah tempat ibadah baik di rumah harus menghadap ke utara (Gunung Rinjani) karena gunung Utama Angga. Kemudian Madya Angga (bagian tengah) yaitu pemukiman dan laut Ampenan serta pemakaman Cakra untuk Nista. Kemudian untuk suatu karang ke posisi Pura utama terletak di paling utama. Kemudian pertengahan pemukiman kemudian kuburan.

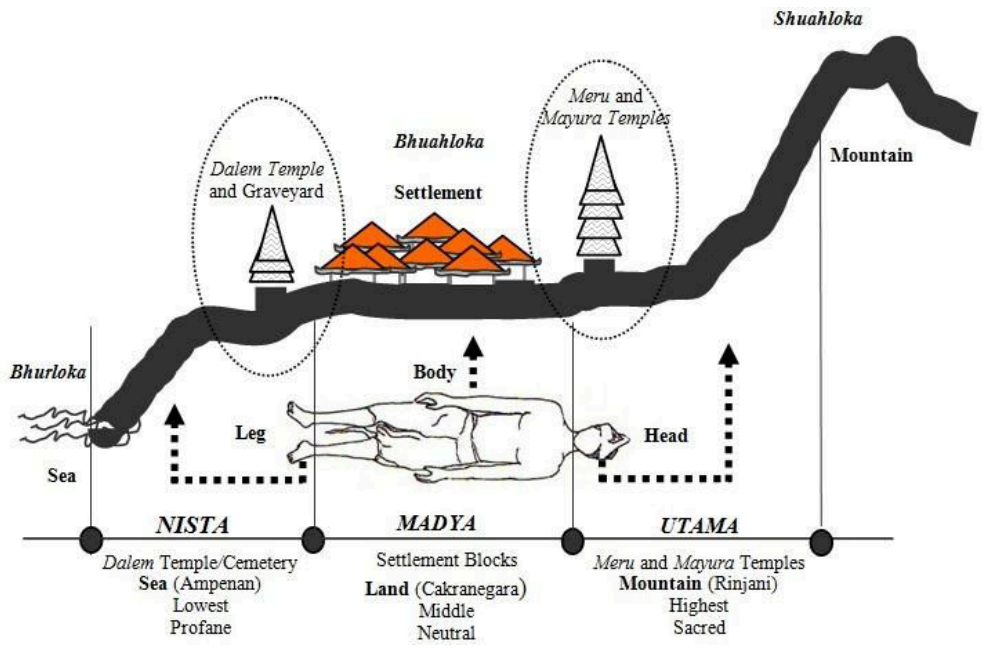

Sehingga dalam posisi rumah, pemukiman, pasar, tempat ibadah mengandung nilai. Dari utama bersih, pemikiran kemudian Nista yang kotor laut maupun pemakaman dan pasar. Ini senada dengan teori Marx Weber Rasionalitas yang berorientasi nilai. Dimana pembangunan kawasan Cakranegara di dasari oleh fengshui asta bumi Bali yang menggunakan konsep tri hita karana, tri angga, tri loka, sangga mandala. Selain posisi perumahan yang mengandung makna atau nilai. Kawasan Cakra juga dibangun berdasarkan sistem keamanan benteng di mana kawasan Cakranegara di bangun seperti roda yang pusat pemerintahan di kawasan
Mayura. Kemudian sistem irigasi yang di atur dari pura Mayura sehingga pertanian di kawasan Cakra tidak minim pasokan air.

2. Pandangan Masyarakat Hindu Mengenai Asta Bumi.

Dilihat dari hasil wawancara terhadap Masyarakat Cakra pemeluk agama Hindu. Masyarakat Hindu Cakra masih berpedoman dalam Asta Bumi baik dalam pembangunan rumah pura dan lain. Hal ini dilakukan secara turun-temurun dan menjadi peganggan mereka. Hal ini dilakukan agar msyarakat terhindar dari hal-hal yang buruk. Seperti halnya tidak boleh mendirikan rumah yang dulunya didirikan pura, bekas kuburan, 
peristiwa bunuh diri, setalah itu perkarangan yang mendatangkan rasa takut yang akan mendatangkan kesusahan, dan kesakitan.

Bahan pemabangunan rumah pun harus selektif dalam pemilihan seperti Bramasesa (tidak boleh menggunakan bahan material sisa kebakaran), Nguringwapke (memakai bekas bahan bangunan yang rubuh tanpa sebab yang jelas), Poman Pamali (menggunakan kayu yang berada di jurang), Anepiluwah (menggunakan kayu yang berada di tepi sungai), Sesawadung (memakai kayu sisa dari tebangan terdahulu), Candragni (memakai kayu yang berada di tempat ibadah keluarga), bhutagraha (kayu yang diambil di kuburan), Pamali Wates (mengambil kayu di tengah pembatas perkaangan), Asurigrha (kayu yang diambil dari tepi danau), Bhutangandang (kayu yang diambil dari pohon yang melintang di jalan), Ngayut Dana (pohon yang diambil dari aliran sungai), Sinarbegelap (kayu yang diambil dari pohon yang tumbang akibat sambaran petir). Apabila tantangan ini dilanggar masyarakat pemeluk agama Hindu percaya akan terjadi musibah seperti penyakit, rasa tidak nyaman, penyakit, pendek umur.

Oleh karena itu masyarakat Hindu sangat memegang teguh tekhnik pembangunan rumah baik itu lokasi, letak, pemilihan material bangunan. Sehingga ditanamkan sejak kecil untuk keselarasan antara alam dan manusia agar tidak terjaddi bencana. Hal ini senada dengan teori Marx Tindakan Tradisional yang dilakukan secara turun-temurun fengshui Asta Bumi yang menggunakan konsep tri hita karana, tri angga, tri loka, sangga mandala. Walaupun terjadi perubahan karena mahalnya harga tanah, anak dan cucu yang banyak sehingga tidak bisa tertampung lagi dalam rumah. Masyarakat Hindu tetap memegang hal-hal yang penting dalam pembangunan seperti posisi tempat ibadah, kemudian pawon (dapur), material yang digunakan dalam pembangunan sehingga tidak terjadi musibah dalam keluarga tersebut.

\section{Pandangan Akademisi dan Pandangan Pemerintah Mengenai Asta Bumi}

Dilihat dari hasil wawancara yang dilakukan Cakranegara dulunya merupakan kerajaan Karangasem (Singasari), tetapi akibat perselisihan kekuasaan kerajaan Karangasem bentrok dengan kerajaan Mataram yang bergabung dengan kerajaan Pagutan. Kerajaan Karangasem (Singasari) pun mengalami kekalahan sehingga kawasan dikuasai oleh kerajaan Mataram. Dilihat dari pernyataan sejarawan Ahmad JD kawasan Cakra selain dijadikan tempat pemukiman warga pemeluk agama Hindu juga dijadikan laipasan benteng berbentuk lingkaran yang mengelilingi Cakra. Kawasan Cakra pun mengalami beberapa perkemabangan seperti halnya ketika pemerintahan belanda masuk ke Lombok. Kawasan Cakra terutama lahan yang sekarang Mataram Mall dulunya adalah tempat hiburan dan sport pacuan kuda. Kemudian perpindahan pusat pemerintahan dari kawasan Cakra ke Mataram. Pada masa pemerintahan Orba.

Cakranegara beralih pungsi menjadi pusat perdaganggan selain Ampenan hal ini dikarenan penggungsi Tionghoa dari Lombok Timur. Kemudian di Cakranegara dulunya terdapat terminal. Tapi dengan seiring waktu di pindahkan ke sweta. Kemudian sesuai dengan perda no 12 tahun 2012 kawasan secara resmi dijadikan pusat bisnis dan budaya. Dengan ditetapkannya kawasan Cakra sebagai kawasan bisnis dan budaya, pemerintah mulai memperbaiki beberapa sektor jalan yang mukanya kurang lebar mulaidi lebarkan hal ini dikarenakan mulai padatnya kendaraan miliki pribadi. Kemudian mulai ditatanya kawasan pengguna jalan kaki serta sepeda setelah itu unutk mengurangi kepadatan penduduk dan rumah kumuh pemkot sudah embangun rusunawa di kawasan Cakra Timur juga masih di canangkannya tempat 
parkir. Bila dikaitkan dengan teori Marx Weber, toeri rasionalitas instrumental sangat berkaitan.

$\mathrm{Hal}$ ini bisa di lihat dari perencanaan kawasan Cakra. Di jaman pemerintahan Belanda kawasan dijadikan salah satunya sebagai kawasan hiburan. Kemudian dengan adanya migrasi masyarakat minoritas dari Lotim ke kawasan Cakra secara tidak langsung kawasan tersebut menjadi kawasan perdaganggan dan posisi pemerintah mulai menata, seperti didirikannya pasar Cakra, kemudian terminal. Dengan berkembangnya zaman. Kawasan Cakra memiliki daya tarik dan potensi seperti yang dilihat banyak didirikan hotel dan wisma, serta kawasan budaya dan beberapa peninggalan sejarah Lombok. Sehingga pemeritah terhitung sejak tahun 2012 menjadikan kawasan Cakra sebagai pusat bisnis dan budaya.

\section{PENUTUP}

A. Kesimpulan

1. Ciri Khas Asta Bumi yang Berada di Kawasan Cakranegara

Asta Bumi merupakan pedoman bagi masyarakat Hindu untuk membangun suatu perkarangan baik rumah maupun karang. Asta Bumi sendiri menselaraskan kehidupan antara manusia dengan alam. Dan menggunakan konsep tubuh manusia. Kepala disebut utama angga, badan madya angga dan yang terakhir kaki angga. Seperti halnya di kawasan Cakranegara dimana terkonsep dari Wilyah utama angga Gunung rinjani, madya pemukiman serta nista pantai Ampenan.

2. Pandangan Masyarakat Hindu Cakranegara Mengenai Asta Bumi

Tata ruang kota yang di pakai kerajaan Karangasem Lombok berbeda dengan konsep di Bali ini bisa dilihat dari lebar jalan, kemudian pola grid yang digunakan seperti papan catur. Maksud dan tujuan tersebut agar terjadi keharmonisan antara pemeluk agama Hindu dengan agama Islam.
Tetapi dengan seiringnya waktu masyarakat Hindu mulai meninggalkan konsep Asta Bumi seperti halnya luas rumah. Hal ini di karenakan banyak anak, serta cucu, kemudian harga tanah yang mahal. Sehingga masyarakat Hindu memilih tanah yang kecil. Walau terbatas luas masyarakat Hindu tetap mempertahankan posisi tempat semabahyang (pura), paon (dapur), tempat berkumpul.

3. Pandangan Akademisi dan Pandangan Pemerintah Mengenai Asta Bumi

Menurut pandagan akademisi konsep Asta Bumi yang digunakan di kawasan Cakra sangat unik. Karena berbentuk catur, serta untuk benteng pertahanan pada awalnya selain sebagai tempat pemukiman masyarakat Hindu Bali. Untuk sistemp pengairan pun tertata rapi ini masih bisa dilihat sampai sekarang kawasan taman Mayura tetap mengaliri air ke limbah pembuangan dan belum pernah terjadi banjir.

Tapi dengan seiringnya waktu, walau sudah tertata ruang semakin sempit hal ini dikarenakan kendaraan pribadi yang semakin meningkat dan terjadi kemaceta, kemudian terjadi parkir liar sehingga Pemkot Mataram berinisiatif memperluas jalan, kemudian dengan disetujuinya daerah Cakra sebagai tempat bisnis dan budaya. Cakranegara mulai dipermak seperti disediakan jalan untuk pejalan kaki, penanaman pohon dipinggir, penertiban izin bangunan.

\section{B. Saran}

Untuk aparat pemerintah Provinsi Nusa Tenggara Barat, hendaknya mulai menggunakan pondasi dasar tata kota seperti kawasan kota Cakranegara. Pada pembangunan kawasan yang akan dibangun. Sehinggan teratur rapi.

Bagi peneliti, dari hasil penelitian ini akan dapat menjadi suatu pedoman untuk melakukan kajian yang lebih mendalam mengenai hal-hal yang menyangkut masalah tata kota di kawasan Cakranegara dalam persefektif sejarah guna menambah wawasan khasanah ilmu pengetahuan tata kota yang ada di pulau Lombok 


\section{DAFTAR PUSTAKA}

Abdillah, Aam. 2012. Pengantar IImu Sejarah, Jakarta: CV. Pustaka Setia.

Abdurrahman, Dudung. 2011. Metodologi Penelitian Sejarah Islam, Yogyakarta: Ombak.

Arif, Muhammad. 2011. Pengantar Kajian Sejarah, Bandung: Yrama Widya.

Arrafiani. 2012. Rumah Etnik Bali. Depok: Griya Kreasi.

Chuckybugiskha. 2011. Letak Geografis Indonesia. Diambil Tangal 25 April 2015

dari http:///bugiskha.wordpress.com/201 1/11/29/letak-wilayah-Indonesia/.

Budihardjo, Eko. 2009. Penataan Ruang dan Pembangunan Perkotaan. Bandung: P. T. Alumni.

Cool, Capt. W. (1896). De Lombok Expeditie, Batavia, G. Kolt dan CO.

Funo, S. (1995). Cakranegara, A Unique Hindu City in Lombok (Indonesia) The Grid in the Tradition of Asian City Planning, Makalah yang disampaikan dalam Seminar Arsitektur Nusantara, Keajekan dan Perubahan, World Trade Centre, Surabaya.

Kartodirjo, Sartono, Ilmu Sosial dalam Metodologi Sejarah, [pdf], (, diakses tanggal 17 september 2009)

Kraan, Alfons van der. 2009. Lombok Penaklukkann, Penjajahan, dan Keterbelakangan. Mataram. Lengge Printika

Paeni, Muklis. 2009. Sejarah Kebudayaan Indonesia Arsitektur. Jakarta: PT Rajagrafindo Persada.

Pany, Hermansyah. 2015. Mudjitahid Kepemimpinan Sasak-Nusantara. Lombok: Bani Akbar.

Parimartha, I Gede. 2014. Lombok Abad XIX Politik, Perdagangan, dan Konflik di Lombok 1831-1891. Denpasar: Pustaka Larasan.

Said, Rahmat. 2011, Analisis Data Penelitian Kualitatif Model Miles dan Huberman, [online], (http://www.Pendidikan Dan Guru Penelitian Kualitatif.go.id) Model Miles dan Huberman.htm, diakses tanggal 11 juli 2011.

Suprapto. 2013. Semerbak Dupa di Pulau Seribu Masjid Konsistensi, Integrasi, dan Resolusi Konflik Hindu-Muslim. Jakarta: Kencana.

Sjamsuddin, Helius. 2012. Metodologi Sejarah, Yogyakarta: Ombak.

Suwondo, Bambang. 1977/1978. Sejarah Daerah Nusa Tenggara Barat. Lombok: Departemen Pendidikan dan Kebudayaan.

Tarigan, Robinson. 2007. Perencanaan Pembangunan Wilayah. Jakarta: Pt. Bumi Aksara. 